Berkala Ilmu Perpustakaan dan Informasi, Vol. 13, No. 1, Juni 2017, Hal. 97-106 DOI: http://10.22146/bip.26069

ISSN 1693-7740 (Print), ISSN 2477-0361 (Online)

Tersedia online di https://jurnal.ugm.ac.id/bip

\title{
LITERASI INFORMASI PUSTAKAWAN DI PERPUSTAKAAN FAKULTAS TEKNIK UGM MENGGUNAKAN PENGEMBANGAN MODEL THE BIG6
}

\author{
Yudistira $^{1}$ \\ ${ }^{1}$ Pustakawan Universitas Gadjah Mada \\ e-mail: yudistira.geologi@mail.ugm.ac.id
}

Naskah diterima: 5 April 2017, direvisi: 9 Mei 2017, disetujui: 12 Juni 2017

\begin{abstract}
ABSTRAK
Penelitian ini bertujuan untuk mengetahui literasi informasi pustakawan di Perpustakaan Fakultas Teknik UGM berdasarkan model the big6 dan untuk mengetahui tahapan-tahapan literasi informasi pustakawan di Perpustakaan Fakultas Teknik UGM untuk masing-masing tahapan berdasarkan model the big6. Metode yang peneliti gunakan dalam penelitian ini adalah deskriptif kuantitatif. Penelitian ini merupakan penelitian populasi, dimana seluruh populasi dijadikan sampel penelitian. Populasi dalam penelitian ini adalah seluruh pustakawan di Perpustakaan Fakultas Teknik UGM yang berjumlah 4 orang. Analisis data menggunakan rumus mean \& grand mean. Berdasarkan data yang telah diolah diketahui bahwa literasi informasi pustakawan di Perpustakaan Fakultas Teknik UGM tergolong dalam kategori baik dibuktikan dengan nilai grand mean sebesar 3,20. Dari tahapan definisi masalah tergolong sangat baik dengan nilai 3,28. Dari tahapan strategi pencarian informasi, tergolong sangat baik dengan nilai 3,27. Dari tahapan tahapan lokasi dan akses, tergolong sangat baik dengan nilai 3,38. Dari tahapan penggunaan informasi, tergolong baik dengan nilai 2,88. Dari tahapan sintesa, tergolong baik dengan nilai 3,21. Dari tahapan evaluasi, tergolong baik dengan nilai 3,20. Penelitian ini diharapkan dapat memberikan masukan kepada perpustakaan untuk mempertahankan dan meningkatkan keterampilan dalam bidang literasi informasi.
\end{abstract}

Kata kunci: Literasi Informasi, Pustakawan, The Big6 Model

\section{ABSTRACT}

This research aims to know librarian literacy information in the Library of Faculty of Engineering UGM based on the big6 model and to know the stages of librarian literacy information in the Library of Faculty of Engineering UGM for each stage based on the big6 model. The method that the researchers use in this research is descriptive quantitative. This research is a population study, where the entire population is used as a research sample. The population in this research is all librarians in the Library Faculty of Engineering UGM which amounted to 4 people. Data analysis using mean \& grand mean formula. Based on the data that has been processed it is known that librarian literacy information in the Library of Faculty of Engineering UGM belong to the category well proved with the grand mean value of 3.20. From the stages the definition of the problem is very good with a value of 3.28. From the stages of information search strategy, classified very well with a value of 3.27. From the stages of the location and access stage, it is very good with 3.38. From the stages of the use of information, quite well with the value of 2.88. From the synthesis stage, it is quite good with a value of 3.21. From the evaluation stage, it is good with 3.20. This research is expected to provide input to the library to maintain and improve skills in the field of information literacy.

Keyword: Information Literacy, Librarians, The Big6 Model. 


\section{A. PENDAHULUAN}

\section{Latar Belakang}

Era milenium ditandai dengan berkembangnya teknologi informasi dan komunikasi yang berdampak pada mudahnya seseorang memperoleh akses terhadapinformasi. Setiap hari jutaan informasi dihasilkan dalam berbagai bentuk media. Fakta tersebut menunjukan bahwa ledakan informasi tidak bisa terbendung dan tersebar luas yang mengakibatkan data semakin kompleks dan beragam.

Banyaknya informasi yang tersedia saat ini apakah menjadikan seseorang mampu mencari, menggunakan, mengevaluasi dan memanfaatkan dengan efektif? Sesungguhnya memiliki informasi bukan berarti semua kebutuhan akan informasi dapat terpenuhi. Hal ini disebabkan informasi yang dimiliki tidak sesuai dengan apa yang dibutuhkan, atau informasi yang dimiliki tidak bisa dipertanggungjawabkan kebenarannya. Kemampuan untuk mendapatkan informasi dalam pemenuhan kebutuhan informasi tidak muncul dengan sendirinya, sehingga kemampuan untuk mendapatkan informasi adalah kemampuan yang dimiliki oleh setiap orang dengan tingkat kemampuan yang berbeda-beda. Tingkat kemampuan inilah yang menentukan seberapa baik hasil dari analisis informasi yang ditemukan atau produk informasi yang dihasilkan.

Kemampuan dalam mencari, mengevaluasi, mengorganisasikan serta menggunakan informasi secara efektif akan menghasilkan keterampilan yang diperlukan bagi seorang pustakawan dalam menjalankan tugas sehari-hari, termasuk mengajarkan literasi informasi kepada pemustaka.

Sehubungan dengan kelimpahruahan informasi yang dinyatakan di atas, maka seharusnya mahasiswa juga memiliki kemampuan literasi informasi dalam belajar. Hal ini tidak saja mendukung mahasiswa yang bersangkutan untuk dapat belajar dan menyelesaikan studi dengan efektif, namun hal itu akan mendukung mahasiswa untuk belajar berbagai keterampilan literasi informasi, mengakses dan memperbaharui pengetahuannya sebagai bekal untuk bekerja. (Solomon, 2012 dalam Baskoro, 2015)

Perpustakaan Fakultas Teknik UGM merupakan salah satu dari perpustakaan yang ada di UGM. Pada 2010-2011 secara fisik perpustakaan Fakultas Teknik bertransformasi menjadi sebuah gedung perpustakaan yang megah dan dapat dikatakan mewah. Pada tahun 2012 perpustakaan
Fakultas Teknik mengalami pergantian kepemimpinan. Di bawah pemimpin yang baru ini perpustakaan Fakultas Teknik semakin berbenah ke arah lebih baik. Banyak terobosan-terobosan baru yang dilakukan untuk memberikan pelayanan yang lebih baik. Pengelola perpustakaan berusaha untuk melakukan sinergi antara perpustakaan, mahasiswa, dan dosen guna mendukung kegiatan Tri Dharma Perguruan Tinggi.

Kondisi perpustakaan Fakultas Teknik saat ini, pustakawan dituntut untuk memiliki keterampilanketerampilan atau soft skills dalam mengelola informasi dan menyajikannya kepada pemustaka. Salah satu keterampilan yang harus dimiliki adalah menguasai literasi informasi. Dengan menguasai literasi informasi, pustakawan akan mudah menyeleksi informasi yang relevan dan berkualitas sesuai dengan kebutuhan pemustaka.

Berdasarkan masalah yang telah diutarakan di atas maka penulis tertarik untuk mengkaji literasi informasi pustakawan di Perpustakaan Fakultas Teknik UGM dengan menggunakan pengembangan model Big6.

\section{Tujuan Penelitian}

Peneltian ini bertujuan untuk mengetahui tingkat literasi informasi pustakawan di perpustakaan Fakultas Teknik dalam mendefinisikan masalah informasi, menentukan strategi pencarian informasi, menentukan lokasi dan akses informasi, menggunakan informasi, mensintesa informasi, dan mengevaluasi informasi.

\section{Manfaat Penelitian}

Manfaat dari penelitian ini adalah:

a. Hasil penelitian ini dapat dijadikan barometer terhadap sejauh mana tingkat literasi informasi yang dimiliki pustakawan di perpustakaan Fakultas Teknik UGM.

b. Memberi pemahaman tentang pentingnya menguasai lierasi informasi di era globalisasi informasi.

\section{B. TINJAUAN PUSTAKA}

\section{Pengertian Literasi Informasi}

Literasi informasi pertama kali ditemukan oleh American Information Industry Association Paul G.Zurkowski pada tahun 1974 dalam proposalnya yang ditunjukan kepada The National Commission on Libraries and Information Science (NCLIS) di Amerika Serikat. Paul Zurkowski 
menggunakan ungkapan tersebut untuk menggambarkan "teknik dan kemampuan" yang dikenal dengan istilah literasi informasi yaitu kemampuan untuk memanfaatkan berbagai alat-alat inforamsi serta sumber-sumber informasi primer untuk memecahkan masalah mereka (Zurkowski, 1974). Lebih lanjut, Zurkowski mengusulkan bahwa keterampilan literasi informasi harus diimplementasikan secara nasional karena urgensinya yang tidak dapat ditawar-tawar lagi berkaitan dengan prediksi tentang perkembangan jumlah informasi baik dalam hal jumlah, media dan teknologi yang akan terus meningkat.

Dalam penelitian yang diselenggarakan oleh Delphi Study dan dilaporkan kepada National Forum of Information Literacy, Christina Doyle menjelaskan definisi literasi inforamsi sebagai "kemampuan untuk mengakses, mengevaluasi dan menggunakan informasi dari berbagai sumber yang variatif" (Doyle, 1992 dalam Baskoro, 2015).

Menurut ALA (America Library Association) dalam Presidential Committee on Information Literacy dikatakan bahwa "information literacy is a set of abilities requiring individuals to recognize when information is needed and have the ability to locate, evaluate, and use effectively the needed information" (ALA, 1989).

Selain itu menurut The Society of College, National and University Libraries (SCONUL) menyatakan bahwa "Manusia yang memiliki literat informasi akan mendemonstrasikan sebuah kesadaran bagaimana mereka mengumpulkan, menggunakan, mengatur, mensistesis, dan menciptakan informasi-informasi dan data secara etis dan memiliki keahlian informasi untuk melakukannya dengan efektif' (SCONUL, 2011).

Definisi lain diberikan oleh Verzosa (2009) bahwa literasi informasi diartikan sebagai sebuah keahlian dalam mengakses dan mengevaluasi informasi secara efektif untuk memecahkan masalah dan membuat keputusan. Seseorang yang memiliki keahlian ini mengerti bagaimana belajar untuk belajar karena mereka tahu bagaimana mengelola informasi, mengevaluasi, memilah-milah dan menggunakan sesuai dengan etika yang berlaku.

Berdasarkan pendapat di atas, maka penulis dapat menyimpulkan bahwa literasi informasi adalah kemampuan akan melek informasi, kemampuan untuk mencari, menggunakan, mengevaluasi informasi secara cepat dan efisien.

\section{Tujuan Literasi Informasi}

Literasi informasi merupakan kemampuan yang sangat penting untuk dimiliki seseorang terutama dalam dunia akademis. Pada saat ini semua orang dihadapkan dengan berbagai jenis sumber informasi yang berkembang sangat cepat, akan tetapi belum tentu semua informasi itu dapat dipercaya dan sesuai dengan kebutuhan para pencari informasi. Literasi informasi akan membuat orang dapat belajar secara mendiri dan dapat berinteraksi dengan berbagai informasi.

Menurut Doyle dalam Wijetunge (2005) dengan memiliki keterampilan literasi informasi maka seorang individu mampu:

a. Menentukan informasi yang akurat dan lengkap yang akan menjadi dasar dalam mengambil keputusan.

b. Menentukan batasan informasi yang dibutuhkan.

c. Memformulasikan kebutuhan informasi.

d. Mengidentifikasi sumber informasi yang potensial.

e. Mengembangkan strategi penelusuran yang sukses.

f. Mengakses informasi yang dibutuhkan secara efektif dan efisien.

g. Mengevaluasi informasi.

h. Mengorganisasikan informasi.

i. Menggabungkan informasi yang dipilih menjadi dasar pengetahuan seseorang.

j. Menggunakan informasi secara efektif untuk mencapai tujuan tertentu.

Berdasarkan paparan yang telah diuraikan di atas, maka literasi informasi mempunyai tujuan untuk membantu seseorang dalam memenuhi kebutuhan informasinya baik untuk kehidupan pribadi (pendidikan, kesehatan, pekerjaan) maupun lingkup masyarakat.

\section{Manfaat Literasi Informasi}

Dengan memiliki kemampuan literasi informasi kita mudah mengatasi dalam berbagai hal berkaitan dengan kegiatan penelusuran informasi. Literasi informasi bermanfaat dalam persaingan di era globalisasi informasi sehingga pintar saja tidak cukup tetapi yang utama adalah kemampuan dalam belajar secara terus-menerus (Gunawan, 2008). 
Selain itu menurut (Adam, 2009 dalam Dzulikram, 2013) beberapa manfaat literasi informasi yaitu:

1. Membantu mengambil keputusan

Literasi informasi membantu kita dalam mengambil keputusan untuk memecahkan masalah. Ketika orang tersebut memiliki informasi yang cukup maka orang tersebut dapat mengambil keputusan dengan tepat.

2. Menjadi manusia pembelajar di era ekonomi pengetahuan

Dengan memiliki kemampuan literasi informasi maka semakin terbuka untuk selalu melakukan pembelajaran sehingga dapat belajar secara mandiri.

\section{Menciptakan pengetahuan baru}

Seseorang yang memiliki kemampuan literasi informasi akan mampu memilih informasi mana yang benar dan mana yang salah. Sehingga tidak mudah percaya dengan informasi yang diperoleh dan dengan begitu akan muncul pengetahuan baru.

Berdasarkan uraian tersebut di atas, maka dapat diketahui bahwa literasi informasi mempunyai manfaat di era globalisasi informasi bagi semua orang khususnya pustakawan. Pustakawan yang menguasai literasi informasi mampu mengelola, menggunakan dan mengevaluasi inforamsi tersebut menjadi sebuah pengetahuan untuk menyelesaikan suatu masalah dan berguna untuk mengambil suatu keputusan.

\section{Model Literasi Informasi}

Keberadaan model untuk mengidentifikasi berbagai komponen serta menunjukkan hubungan antar komponen. Model literasi biasanya dibuat sebagai acuan pelaksanaan literasi inforamsi di sebuah perpustakaan. Dengan adanya model maka tahapan literasi informasi menjadi lebih jelas. Keterampilan yang dikuasai oleh pemustaka juga lebih jelas, sehingga semua tahapan keterampilan yang dijadikan sebagai sesi pelatihan informasi bisa dikembangkan lebih lanjut sesuai dengan kebutuhan institusi tersebut (Baskoro, 2015).

Sulistyo-Basuki (2012) menyampaikan bahwa ada 4 model informasi yang terkenal yakni The Big 6 , Seven Pillars, Empowering 8 dan the Seven Faces.
1. The Big 6

Model literasi informasi the Big 6 dikembangkan oleh Mike Eisenberg dan Bob Berkowits. Salah satu model literasi informasi yang banyak digunakan di sekolah-sekolah, institusi pendidikan tinggi dan perusahaan. Diambilkan dari Big6.com, model ini mendasarkan identifikasi dalam enam langkah yakni: pendefinisian tugas, strategi pencarian informasi, lokasi dan akses, penggunaan informasi, melakukan sintesis, dan melakukan evaluasi.

Tahap pendefinisian tugas mencoba memperlihatkan bagaimana masalah informasi didefinisikan dan identifikasi kebutuhan. Tahap strategi pencarian informasi dilakukan dengan menentukan semua sumber-sumber informasi yang ada dan kemudian memilih yang terbaik. Tahap penentuan lokasi dan akses merupakan tahap melakukan pencarian dan menemukan informasi dalam sumber-sumber yang ada. Kemudian tahap penggunaan informasi yakni bagaimana kita menghadapi informasi yang telah diperoleh dan mengekstrasi dalam informasi-informasi yang relevan. Sedangkan pada tahap sintesis, adalah bagaimana mengorganisasi informasi dari berbagai sumber yang ada dan kemudian menampilkan informasi tersebut atau menyajikan informasi. Tahap terakhir dari proses model ini adalah mengevaluasi dengan cara menilai efektifitas produk dan efisiensi prosesnya.

\section{Seven Pillars}

The 7 Pillars (SCONUL), dari Society of College, berisi 7 langkah Literasi Informasi yang dibuat cenderung disiapkan untuk digunakan dalam universitas, dan perguruan tinggi, yaitu: recognise information need, distinguish way of addressing gap, construct strategies for locating, locate and access, compare and evaluate, organize, apply and communicate, synthesise and create.

Setiap pilar menggambarkan sebuah rangkaian pernyataan yang berhubungan dengan kesatuan keterampilan atau kompetensi dan kesatuan sikap/pemahaman. Sulistyo-Basuki (2012) membagi model tujuh pillar dalam dua himpunan ketrampilan yaitu mengetahui bagaimana menentukan lokasi informasi serta 
mengaksesnya (ketrampilan teknologi informasi), dan mengetahui bagaimana memahami serta menggunakan informasi (ketrampilan dasar perpustakaan). Identify, scope, plan dan gather merupakan pilar yang menggambarkan ketrampilan atau kompetensi terkait teknologi informasi. Sedangkan evaluate, manage, dan present merupakan pilar yang menggambarkan keterampilan terakait pemahaman dan penggunaan informasi.

\section{Empowering 8}

Empowering 8 (E-8) adalah sebuah model pemecahan masalah untuk model pembelajaran berbasis sumber belajar. E-8 dikembangkan pada bulan November 2004 dalam International Workshop on Information Skills for Learning di University of Colombo, Sri Lanka. Kegiatan ini didukung oleh International Federation of Library Association/Action for Development through Library Programme (IFLA/ALP) dan National Institute of Library and Information Science (NILIS) di University of Colombo. Model literasi informasi ini dikembangkan oleh orang-orang Asia untuk orang Asia dan dianggap sebagai model yang merefleksikan kondisi orang-orang Asia. Berisi 8 langkah Literasi Informasi yang terdiri dari : identify, Explore, Select, Organize, Create, Present, Assess, and Apply.

\section{The Seven Faces}

Model ini dikenalkan oleh Bruce dengan menggunakan tiga strategi pendekatan perilaku, pendekatan konstruktivis, dan pendekatan relasional. Pendekatan perilaku yang menggambarkan seorang yang melek informasi harus dapat menunjukkan karakteristik tertentu dan keterampilan tertentu yang dapat diukur. Pendekatan konstruktivis memberikan tekanan kepada pembelajar dalam mengkonstruksi gambaran domainnya, seperti pembelajaran berbasis persoalan. Pendekatan relasional yang dimulai dengan menggambarkan fenomena dalam bahasa yang dialami seseorang(SulistyoBasuki 2012).

Pada model ini terdapat tujuh wajah literasi informasi yakni konsepsi teknologi informasi, konsepsi sumber informasi, konsepsi proses informasi, konsepsi pengendalian informasi, konsepsi konstruksi pengetahuan, konsepsi perluasan pengetahuan dan konsepsi kearifan.
Berdasarkan uraian tersebut di atas, maka penulis lebih memilih untuk menggunakan model Big6 karena banyak diaplikasikan di institusiinstitusi termasuk bagi perguruan tinggi.

\section{Pustakawan}

Menurut Undang-Undang Nomer 43 Tahun 2007 disebutkan bahwa pustakawan adalah seseorang yang memiliki kompetensi yang diperoleh melalui pendidikan serta mempunyai tugas dan tanggung jawab untuk melaksanakan pengolahan dan pelayanan perpustakaan.

Selain itu Sulistyo-Basuki (1993) menyatakan bahwa pustakawan adalah tenaga profesional yang dalam kehidupan sehari-hari yang berkecimpung dalam dunia buku. Sedangkan menurut Soetminah (1992) menyatakan pustakawan adalah pegawai negeri sipil yang yang berijazah di bidang perpustakaan, dokumentasi dan informasi yang diberi tugas secara penuh oleh pejabat yang berwenang untuk melakukan kegiatan perpustakaan dan dokumentasi pada unit-unit perpustakaan instansi pemerintah dan atau unit tertentu lainnya. Unit perpustakaan adalah satuan kerja perpustakaan yang sekurang-kurangnya mempunyai 1.000 judul bahan pustaka yang terdiri sekurang-kurangnya atas 2.500 eksemplar dan dibentuk dengan keputusan pejabat yang berwenang.

Jadi yang dimaksud pustakawan dalam penelitian ini adalah seseorang yang memiliki kompetensi yang diperoleh melalui pendidikan dan/atau pelatihan kepustakawanan serta mempunyai tugas dan tanggung jawab untuk melaksanakan pengolahan dan pelayanan perpustakaan.

\section{Pustakawan dan Literasi Informasi}

Peran pustakawan dalam melayani penggunanya sangat beragam. Salah satunya adalah sebagai "manajer informasi" yang mengelola informasi pada satu sisi, dengan pengguna informasi pada sisi lain. Informasi yang banyak dan terdapat dalam berbagai wadah yang jumlahnya selalu bertambah harus dikelola dengan baik (Hermawan S. dan Zen, 2010).

Sedangkan (Pendit, 2003) menyatakan bahwa tugas fungsi pustakawan antara lain adalah mendukung dan memastikan kelancaran proses pembentukan pengetahuan lewat layanan-layanan informasi yang diberikannya. Oleh karena itu, pustakawan harus mampu menentukan jenis-jenis informasi yang sesuai dengan penggunanya. Dengan 
kata lain, peran pustakawan adalah sebagai penyaji informasi yang relevan dan berkualitas. Pustakawan harus mampu menyediakan fasilitas, suasana, dan sistem yang memungkinkan pencarian pencarian dan penemuan informasi yang relevan dan berkualitas di tengah banjir informasi yang semakin deras melanda para pengguna perpustakaan dan para pencari informasi pada umumnya.

Sejalan dengan pokok pikiran di atas, Naibaho (2011) menyatakan bahwa tugas pustakawan tidak bisa dipisahkan dari tugas dan fungsi perpustakaan sebagai lembaga penyedia dan pengelola informasi yang bertugas memberikan akses seluas-luasnya bagi pengguna untuk mendapatkan informasi yang tepat secara efisien. Selain sebagai sumber informasi, perpustakaan juga merupakan sebuah instansi non formal yang menyediakan koleksi dan informasi yang beraneka ragam dan berguna untuk mengubah cara berfikir, bertingkah laku dan berperasaan dalam menghadapi kehidupan yang terus berubah. Fungsi inilah yang menjadi kunci atau rujukan bagi pustakawan dalam menjalankan tugasnya, dimana pustakawan tidak cukup hanya menyediakan akses informasi, tetapi juga menyediakan informasi tersebut bermanfaat bagi penggunanya dalam rangka mencapai masyarakat cerdas dan berpikir kritis.

Berdasarkan beberapa pendapat di atas peran dan tugas pustakawan adalah pustakawan sebagai penyaji informasi yang relevan dan berkualitas sesuai dengan kebutuhan para pemustaka, pustakawan dituntut menguasai keterampilan dalam menelusur informasi atau literasi informasi.

Dengan menguasai literasi informasi, kemampuan pustakawan akan berkembang sehingga diharapkan bisa:

1. Menggabungkan minat, keterampilan, dan kepercayaan diri dalam menulis mengenai pekerjaan dan pengetahuan di bidang kepustakawanan dan informasi.

2. Menghasilkan karya tulis dalam berbagai bentuk, terutama yang dapat meningkatkan profesionalisme pustakawan.

3. Mengidentifikasi dan mengumpulkan tulisan yang dapat dikembangkan lebih lanjut dan disebar luaskan melalui berbagai media (blog, majalah internal, jurnal, dan sebagainya).

\section{METODE PENELITIAN}

Penelitian mengenai literasi informasi pustakawan di perpustakaan Fakultas Teknik UGM menggunakan pengembangan model Big6 adalah dengan menggunakan metode deksriptif kuantitatif. Perhitungan kuantitatif dilakukan untuk mengelola instrumen kuesioner atau angket. Hasil angka kuantitatif tersebut akan diterjemahkan secara deskriptif untuk mendapatkan kesimpulan hasil kajian.

Menurut Narbuko dan Achmadi (2009) penelitian deskriptif adalah penelitian yang berusaha untuk menuturkan pemecahan masalah yang ada sekarang berdasarkan data-data, jadi penelitian deskriptif juga menyajikan data, menganalisis dan menginterpretasi.

\section{Populasi dan Sampel}

Menurut Sugiyono (2006) populasi adalah wilayah generalisasi yang terdiri atas objek atau subjek yang mempunyai kualiatas dan karakteristik tertentu yang ditetapkan oleh peneliti untuk dipelajari dan kemudian ditarik kesimpulannya.

Populasi dalam penelitian ini adalah pustakawan di Perpustakaan Fakultas Teknik UGM. Pustakawan dalam penelitian ini adalah sesuai dengan yang telah dijelaskan dalam landasan teori, yaitu seseorang yang bekerja di perpustakaan atau lembaga informasi sejenisnya yang memiliki keahlian dan keterampilan di bidang ilmu perpustakaan, dokumentasi, dan informasi yang diperoleh melalui pendidikan formal maupun non formal serta memiliki tugas dan tanggung jawab untuk melaksanakan pengelolaan dan pelayanan perpustakaan. Data yang diperoleh jumlah pustakawan adalah 4 orang.

Tabel 1.

Pustakawan di Perpustakaan Fakultas Teknik UGM

\begin{tabular}{cll}
\hline No & \multicolumn{1}{c}{ Nama } & \multicolumn{1}{c}{ Jabatan } \\
\hline 1. & Puwoko, SIP, M.A. & Penanggung Jawab Perpustakaan \\
2. & Bagus Wijaya, SIP, S.Kom. & Layanan Digital \\
3. & Sugeng, A.Md. & Pengolahan Bahan Pustaka \\
4. & Isnaini Syamsiati, S.Sos. & Layanan Sirkulasi \\
\hline
\end{tabular}

Penelitian ini merupakan penelitian populasi, di mana seluruh populasi menjadi sampel penelitian atau total sampling. Dengan demikian, seluruh pustakawan di Perpustakaan Fakultas Teknik UGM dijadikan responden.

\section{Instrumen Penelitian}

Sugiyono (2006) menyebutkan instrument penelitian adalah suatu alat yang digunakan mengukur fenomena alam maupun sosial yang diamati. Metode yang digunakan untuk 
mengumpulkan data dalam penelitian ini adalah metode kuesioner atau angket, yang berisi butir-butir pertanyaan yang akan diisi oleh responden. Jenis kuesioner dalam penelitian ini adalah kuesioner tertutup, dengan skala inkeles, yaitu sejenis kuesioner tertutup, seperti tentang prestasi belajar bentuk pilihan ganda yang terdiri empat alternatif jawaban, karena diharapkan responden lebih cepat menentukan pilihannya (Arikunto, 2002).

Penulis menggunakan kuesioner tertutup dengan skala inkeles karena memberi kemudahan kepada responden dalam memberikan jawaban dan lebih praktis serta sistematis. Adapun isi kuisioner didasarkan pada teori yang telah dikemukakan di atas mengenai Big6 antara lain:

Tabel 2

Kisi-kisi instrument penelitian

\begin{tabular}{|c|c|c|}
\hline Varibel & Sub Variabel & Indikator \\
\hline \multirow{6}{*}{$\begin{array}{l}\text { Literasi } \\
\text { informasi } \\
\text { pustakawan }\end{array}$} & $\begin{array}{l}\text { 1. Definisi } \\
\text { masalah }\end{array}$ & $\begin{array}{l}\text { 1. Mendefinisikan } \\
\text { masalah informasi } \\
\text { 2.Mengidentifikasikan } \\
\text { kebutuhan informasi }\end{array}$ \\
\hline & 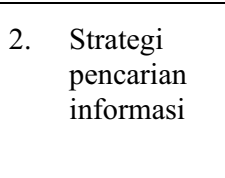 & $\begin{array}{l}\text { 1.Menetapkan semua } \\
\text { sumber yang dapat } \\
\text { digunakan } \\
\text { 2.Menyeleksi sumber } \\
\text { terbaik }\end{array}$ \\
\hline & $\begin{array}{l}\text { 3. Lokasi dan } \\
\text { akses }\end{array}$ & $\begin{array}{l}\text { 1.Melokasikan sumber- } \\
\text { sumber (baik isi } \\
\text { maupun fisik) } \\
\text { 2.Menemukan } \\
\text { informasi dalam } \\
\text { sumber-sumber yang } \\
\text { ada }\end{array}$ \\
\hline & $\begin{array}{l}\text { 4. Penggunaan } \\
\text { informasi }\end{array}$ & $\begin{array}{l}\text { 1.Menghubung- } \\
\text { hubungkan informasi } \\
\text { 2.Menyarikan informasi } \\
\text { yang relevan }\end{array}$ \\
\hline & 5. Sintesa & $\begin{array}{l}\text { 1.Mengorganisasi } \\
\text { informasi dari } \\
\text { berbagai sumber } \\
\text { 2.Mempresentasikan } \\
\text { informasi }\end{array}$ \\
\hline & 6. Evaluasi & $\begin{array}{l}\text { 1.Menilai produk } \\
\text { 2.Menilai proses }\end{array}$ \\
\hline
\end{tabular}

\section{HASIL DAN PEMBAHASAN}

Hasil penelitian mengenai Literasi Informasi Pustakawan di Perpustakaan Fakultas Teknik UGM berdasarkan pengembangan model The Big6.

\section{Sub Variabel Definisi Masalah}

Indikator definisi masalah meliputi mendefinisikan masalah informasi yang akan dicari dan mengidentifikasi kebutuhan informasi. Terdapat 5 butir pernyataan untuk mengukur indikator dari sub variabel definisi masalah. Kemudian dari tiaptiap butir pernyataan tersebut diolah menggunakan rumus mean sehingga diperoleh nilai rata-ratanya.

Tabel 3

Hasil ringkasan nilai sub variabel definisi masalah

\begin{tabular}{|c|c|c|c|}
\hline No & Indikator & $\begin{array}{c}\text { Nilai Rata- } \\
\text { Rata } \\
\end{array}$ & Kategori \\
\hline 1 & \multirow{3}{*}{$\begin{array}{l}\text { Mendefinisikan } \\
\text { masalah informasi }\end{array}$} & 3,50 & Sangat Baik \\
\hline 2 & & 3,35 & Sangat Baik \\
\hline 3 & & 3,30 & Sangat Baik \\
\hline 4 & Mengidentifikasikan & 3,29 & Sangat Baik \\
\hline \multirow[t]{2}{*}{5} & kebutuhan informasi & 3 & Baik \\
\hline & Jumlah & 16,44 & \\
\hline
\end{tabular}

Data yang diperoleh tabel 3 di atas kemudian nilai diolah menggunakan rumus grand mean, yaitu dengan cara menjumlahkan nilai total rata-rata hitung dibagi jumah pernyataan. Sehingga dapat diketahui sub variabel definisi masalah secara keseluruhan nilai rata-ratanya adalah 3,28 dan dapat dikategorikan sangat baik.

\section{Sub Variabel Strategi Pencarian Informasi}

Sub variabel strategi pencarian informasi meliputi menetapkan semua sumber yang dapat digunakan dan menyeleksi sumber terbaik. Terdapat 4 butir pernyataan untuk mengukur sub variabel strategi pencarian informasi.

Tabel 4

Hasil ringkasan nilai sub variabel strategi pencarian informasi

\begin{tabular}{clrl}
\hline No & Indikator & $\begin{array}{c}\text { Nilai Rata- } \\
\text { Rata }\end{array}$ & Kategori \\
\hline 6 & Menetapkan semua & 3,05 & Baik \\
7 & sumber yang dapat & 3,52 & Sangat Baik \\
8 & digunakan & 3,50 & Sangat Baik \\
& Menyeleksi sumber & 3,01 & Baik \\
9 & terbaik & 13,08 & \\
\hline & Jumlah &
\end{tabular}

Data yang diperoleh tabel 4 di atas, dapat diketahui bahwa nilai keseluruhan sub variabel strategi pencarian informasi setelah dihitung menggunakan rumus grand mean adalah 3,27 dan termasuk dalam kategori sangat baik.

\section{Sub Variabel Lokasi dan Akses}

Tahap ini merupakan tahap dimana seseorang harus memiliki kemampuan untuk menggunakan indeks. Hampir semua informasi yang berbentuk cetak dan elektronik tersusun dalam indeks, agar memungkinkan ditemukan kembali dengan cepat. Terdapat 4 pernyataan untuk mengukur indikator dari sub variabel lokasi dan akses. 
Tabel 5

Hasil ringkasan nilai sub variabel lokasi dan akses

\begin{tabular}{llrl}
\hline No & Indikator & $\begin{array}{c}\text { Nilai Rata- } \\
\text { Rata }\end{array}$ & Kategori \\
\hline 10 & Melokasikan sumber- & 3,47 & Sangat Baik \\
11 & sumber (baik isi & 3,62 & Sangat Baik \\
12 & maupun fisik) & 3,55 & Sangat Baik \\
& Menemukan informasi & & \\
13 & dalam sumber-sumber & 2,88 & Baik \\
& yang ada & & \\
\hline & Jumlah & 13,52 & \\
\hline
\end{tabular}

Data yang diperoleh tabel 5 di atas, dapat diketahui bahwa nilai keseluruhan dari sub variabel lokasi dan akses setelah dihitung menggunakan rumus grand mean adalah 3,38 dan termasuk dalam kategori sangat baik.

\section{Sub Variabel Penggunaan Informasi}

Dalam tahap ini kita dihadapkan pada masalah pencarian cara yang efektif untuk menyaring dan memeras informasi yang banyak jumlahnya tersebut menjadi informasi yang terseleksi dan siap dipakai dalam berbagai permasalahan kita. Jika kasusnya adalah menulis, maka pada tahap ini kita akan dihadapkan pada tahap di mana semua informasi sudah berada dan kita harus menyeleksi informasi yang ada tersebut. Terdapat 4 butir pernyataan untuk mengukur indikator sub variabel penggunaan informasi.

Tabel 6

Hasil ringkasan nilai sub variabel penggunaan informasi

\begin{tabular}{llrl}
\hline No & Indikator & $\begin{array}{c}\text { Nilai Rata- } \\
\text { Rata }\end{array}$ & Kategori \\
\hline 14 & Menghubung- & 2,54 & Baik \\
15 & hubungkan informasi & 3,20 & Baik \\
16 & Menyarikan informasi & 3,15 & Baik \\
17 & yang relevan & 2,66 & Baik \\
\hline & Jumlah & 11,55 & \\
\hline
\end{tabular}

Data yang diperoleh tabel 6 di atas, diketahui bahwa nilai keseluruhan dari sub variabel lokasi dan akses setelah dihitung menggunakan rumus grand mean adalah 2,88 dan termasuk dalam kategori baik.

\section{Sub Variabel Sintesa}

Dalam langkah ini, kita melakukan penggabungan berbagai informasi yang telah didapatkan dan masih tersebar secara konsep. Indikator dari sintesa meliputi mengorganisasi informasi dari berbagai sumber dan mempresentasikan informasi. Terdapat 4 butir pernyataan untuk mengukur indikator dari sub variabel sintesa.
Tabel 7

Hasil ringkasan nilai sub variabel sintesa

\begin{tabular}{clcl}
\hline No & Indikator & $\begin{array}{c}\text { Nilai Rata- } \\
\text { Rata }\end{array}$ & Kategori \\
\hline 18 & Mengorganisasi & 2,75 & Baik \\
& informasi & & Baik \\
19 & dari berbagai sumber & 3,05 & Sangat Baik \\
20 & Mempresentasikan & 3,45 & Sangat Baik \\
21 & informasi & 3,60 & \\
\hline & Jumlah & 12,85 & \\
\hline
\end{tabular}

Data yang diperoleh tabel 7 di atas, dapat diketahui bahwa nilai keseluruhan dari sub variabel sintesa setelah dihitung menggunakan rumus grand mean adalah 3.21 dan termasuk dalam kategori baik.

\section{Sub Variabel Evaluasi}

Dalam tahap ini, diharapkan adalah bagaimana seseorang dapat memberikan penilaian terhadap hasil dan proses yang telah berhasil dilaluinya. Indikator dari evaluasi meliputi menilai produk dan menilai proses. Terdapat 2 butir pernyataan untuk mengukur indikator dari sub variabel evaluasi.

Tabel 8

Hasil ringkasan nilai sub variabel evaluasi

\begin{tabular}{llcl}
\hline No & Indikator & $\begin{array}{c}\text { Nilai Rata- } \\
\text { Rata }\end{array}$ & Kategori \\
\hline 22 & Menilai produk & 3,30 & Sangat Baik \\
23 & Menilai proses & 3,10 & Baik \\
\hline & Jumlah & 6,40 & \\
\hline
\end{tabular}

Data yang diperoleh tabel 8 di atas, dapat diketahui bahwa nilai keseluruhan dari sub variabel sintesa setelah dihitung menggunakan rumus grand mean adalah 3,20 dan termasuk dalam kategori baik.

\section{Analisis Hasil Penelitian Literasi Informasi}

Berdasarkan analisis dari beberapa sub variabel di atas, maka dapat diketahui hasil literasi informasi pustakawan di Perpustakaan Fakultas Teknik UGM seperti tersebut pada tabel 9.

Tabel 9

Hasil ringkasan nilai variabel literasi informasi

\begin{tabular}{llclc}
\hline No & $\begin{array}{l}\text { Sub Variabel } \\
\text { Literasi } \\
\text { Informasi }\end{array}$ & $\begin{array}{c}\text { Nilai } \\
\text { Rata- } \\
\text { Rata }\end{array}$ & Kategori & $\begin{array}{c}\text { Nilai Total } \\
\text { Rata-Rata }\end{array}$ \\
\hline 1 & $\begin{array}{l}\text { Definisi masalah } \\
\text { Strategi pencarian }\end{array}$ & 3,28 & $\begin{array}{l}\text { Sangat } \\
\text { Baik } \\
\text { Sangat }\end{array}$ & \\
& $\begin{array}{l}\text { Stran } \\
\text { informasi }\end{array}$ & 3,27 & $\begin{array}{l}\text { Baik } \\
\text { Sangat }\end{array}$ & 3,20 \\
3 & Lokasi dan akses & 3,38 & Baik & \\
& Penggunaan & & Baik & \\
4 & informasi & 2,88 & Baik & \\
5 & Sintesa & 3,21 & Baik & \\
6 & Evaluasi & 3,20 & Baik & \\
\hline & Jumlah & 19,22 & & \\
\hline
\end{tabular}




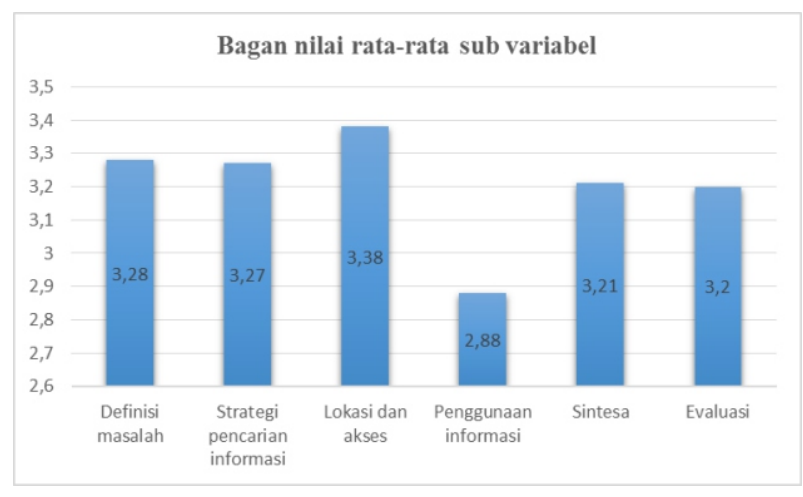

Data yang diperoleh tabel 8 dan bagan di atas dapat dijelaskan bahwa sub variabel lokasi dan akses mempunyai nilai rata-rata lebih tinggi dibandingkan dengan sub variabel lainnya yaitu 3,38 yang berarti tergolong sangat baik. Adapun sub variabel yang mendapatkan nilai rata-rata lebih rendah adalah definisi masalah sebesar 3,28 , sub variabel strategi pencarian informasi sebesar 3,27, sub variabel sintesa sebesar 3,21, sub variabel evaluasi 3,20 dan sub variabel penggunaan informasi mempunyai nilai paling rendah yaitu 2,88 yang berarti responden belum dapat menggunakan informasi dengan baik. Hal ini dapat dilihat dari jawaban responden mengenai butir pernyataan sub variabel penggunaan informasi, sebagian besar responden menjawab kadang-kadang yang berarti responden jarang melakukan analisis terhadap informasi yang didapat.

Secara keseluruhan total nilai rata-rata analisis data literasi informasi yaitu 3,20. Dari rata-rata keseluruhan analisis data literasi informasi tersebut dapat disimpulkan bahwa literasi informasi pustakawan di Perpustakaan Fakultas Teknik UGM berdasarkan pengembangan model the big6 tergolong dalam kategori baik.

\section{E. KESIMPULAN} Kesimpulan

1. Berdasarkan nilai rata-rata keseluruhan tentang literasi informasi pustakawan di Perpustakaan Fakultas Teknik UGM berdasarkan model the big6 secara keseluruhan nilai yang diperoleh yaitu 3,20. Dilihat dari skala interval maka literasi informasi pustakawan di Perpustakaan Fakultas Teknik UGM tergolong dalam kategori baik.

2. Literasi informasi pustakawan di Perpustakaan Fakultas Teknik UGM untuk masing-masing tahapan atau sub variabel berdasarkan pengembangan model the big6 adalah sebagai berikut: a. Nilai sub variabel definisi masalah adalah 3,28, artinya literasi informasi pustakawan dalam mendefinisikan masalah tergolong sangat baik.

b. Nilai sub variabel strategi pencarian informasi adalah 3,27, artinya literasi informasi pustakawan dalam menerapkan strategi pencarian informasi tergolong sangat baik.

c. Nilai sub variabel lokasi dan akses adalah 3,38, artinya literasi informasi pustakawan dalam menentukan lokasi dan akses informasi tergolong sangat baik.

d. Nilai sub variabel penggunaan informasi adalah 2,88 , artinya literasi informasi pustakawan dalam menggunakan informasi tergolong baik.

e. Nilai sub variabel sintesa adalah 3,21 , artinya literasi informasi pustakawan dalam melakukan sintesa/penggabungan terdapat informasi yang didapat tergolong baik.

f. Nilai sub variabel evaluasi adalah 3,20 , artinya literasi informasi pustakawan dalam melakukan evaluasi terhadap produk informasi tergolong baik.

\section{Saran}

1. Perpustakaan Fakultas Teknik UGM perlu mempertahankan dan meningkatkan lagi pelatihan literasi informasi bagi pustakawan, karena keterampilan literasi informasi menjadi sangat penting di era globalisasi informasi. Dengan demikian pustakawan akan mampu memilih dan menyeleksi informasi yang relevan dan berkualitas sesuai kebutuhan para pengguna perpustakaan.

2. Pustakawan dianjurkan untuk mempelajari lebih dalam pada tahapan penggunaan informasi, yaitu dengan cara menganalisis/memeriksa setiap informasi yang diperoleh sebelum informasi tersebut digunakan karena dari informasi yang didapatkan belum tentu sesuai dengan kebutuhan untuk memecahkan masalah yang dihadapi. 


\section{DAFTAR PUSTAKA}

American Library Association. (1989). Presidential Committee on Information Literacy: Final Report. Washington, DC, ALA, US.

Dzulikram, Y. (2013). Kemampuan Literasi Informasi Mahasiswa Pada Layanan American Corner di UPT Perpustakaan IAIN Walisongo Semarang Menurut Association of College and Research Libraries. http://eprints.undip.ac.id/40750/. Download: 5 Oktober 2016,

Arikunto, S. (2002). Prosedur Penelitian: Suatu Pendekatan Praktek. Rineka Cipta, Jakarta.

Baskoro, D. G., \& Jonatan, E. (2015). Kompetensi Literasi Informasi Pustakawan Universitas Swasta di Lingkungan Kopertis Wilayah III. Jurnal Pustakawan Online Tahun 2015, 1-13. http://pustakawan.perpusnas.go.id/jurnal/201 5/index.html. Download: 10 Oktober 2016.

Gunawan, A.W., Lien, D.A., Aruan, D. A., Kusuma, S., \& Adriyanto, S. (2008). 7 Langkah Literasi Informasi: Knowledge Managemen". Universitas Atmajaya, Jakarta.

Hermawan S. R., \& Zen, Z. (2010). Etika Kepustakawanan:Suatu Pendekatan Terhadap Kode Etik Pustakawan Indonesia. Sagung Seto, Jakarta.

Naibaho, K. (2007). Menciptakan Generasi Literat Melalui Perpustakaan. Majalah Visi Pustaka, Vol. 19. No. 3. http://www.perpusnas.go.id/ magazine/menciptakan-generasi-literatmelalui-perpustakaan/ . Download: 8 Oktober 2016.

Narbuko, C., \& Achmadi, A. (2009). Metodologi Penelitian. Bumi Aksara, Jakarta.

Pendit, P. L. (2003). Penelitian Ilmu Perpustakaan dan Informasi: Suatu Pengantar Diskusi Epistimologi dan Metodologi. JIP Fakultas Sastra Universitas Indonesia, Jakarta.
Soetminah. (1992). Perpustakaan Kepustakawanan dan Pustakawan. Kanisius, Yogyakarta.

Sugiyono. (2006). Metode Penelitian Administrasi. Edisi Revisi. Alfabeta, Bandung.

Sulistyo-Basuki. (1993). Pengantar Ilmu Perpustakaan. Gramedia Pustaka Utama, Jakarta.

Sulistyo-Basuki. (2012). "Literasi Informasi dan Literasi Digital." ISIPII Workshop Proceedings". http://sulistyobasuki. wordpress.com $/ 2013 / 03 / 25 / 1$ iterasiinformasi-dan-literasi-digital/. Download: 9 Oktober 2016.

The Society of College, National and University Libraries. (2011). The SCONUL Seven Pillars of Information Literacy: Core Model For Higher Education. UK: SCONUL Working Group on Information Literacy.

Undang-Undang Tentang Perpustakaan Nomer 43 Tahun 2007. http://perpusnas.go.id/ law/undang-undang-nomor-43-tahun-2007tentang-perpustakaan/, Download: 15 Oktober 2016.

Wijetunge, P., \& Alahakoon, U. (2005). Empowering 8: the Information Literacy Model Developed in SriLanka to Underpin Changing Education Paradigms of Sri Lanka. Sri Lanka Journal of Librarianship \& Information Management Vol 1, No. 1 pp.3141. http://doi.org/10.4038/sllim.v1i1.430, Download: 7 Oktober 2016.

Zurkowski, P.G. (1974). The Information Service Environment Relationships and Priorities. Related Paper No. 5. Washington, DC, US: National Commission on Libraries and Information Science, National Program for Library and Information Services. 